\title{
A.JO'厂E
}

African Journal of Teacher Education

ISSN 1916-7822. A Journal of Spread Corporation

Volume 9. No. 22020 Pages 43-61

\section{Knowledge and Awareness of Autism Spectrum Disorder Among Teachers in Ekiti State, Nigeria}

\author{
Benjamin Omolayo ${ }^{1}$, Michael Auta ${ }^{1}$, Elizabeth Akinyemi ${ }^{2}$, Uba Dennis ${ }^{3}$ \\ ${ }^{1}$. Department of Psychology, Federal University, Oye-Ekiti, Nigeria. \\ ${ }^{2}$. Department of Psychology \& Behavioural Studies, Ekiti State University, Ado-Ekiti, Nigeria. \\ ${ }^{3}$ Department of Pure \& Applied Psychology, Adekunle Ajasin University, Akungba-Akoko, Nigeria.
}

\begin{abstract}
This is an investigation of the knowledge and awareness of Autism Spectrum Disorder among secondary school teachers in Ekiti State, Nigeria. It is a school-based cross-sectional study using a multi-stage sampling method to select local government areas, secondary schools, and participants for the study. A total of 107 teachers selected from 21 secondary schools in 2 local government areas participated in the study. A Survey of Knowledge of Autism Spectrum Disorder (ASK-ASD) was used to assess knowledge while an ordinary awareness questionnaire was used to assess the teachers' awareness of the disorder. Using Pearson correlation coefficient and oneway Analysis of Variance to test five hypotheses, results showed no significant relationship between knowledge of Autism Spectrum Disorder and participants having a family or friend with the disorder $(r(105)=-.113 p>.05)$. Finding also revealed a significant relationship between knowledge of Autism and prior training on Autism (r(107) = -.266 p<.05). Age has a significant influence on knowledge of the disorder $(F(2,98)=4.29 p<.05)$ but school type $(F(2,104)=$ $2.506 p>.05)$ and teaching experience $(F(2,103)=1.971 p>.05)$ do not have a significant influence on knowledge of Autism. The result further shows that $96.2 \%$ of the participants were aware of the disorder while $3.8 \%$ were unaware of it. It was recommended that secondary school teachers be equipped with information about Autism Spectrum Disorder through periodic seminars, workshops and conferences.
\end{abstract}

Keywords: Knowledge, Awareness, Autism Spectrum Disorders, Teachers 


\section{Introduction}

Research directed towards the understanding and management of Autism Spectrum Disorder (ASD) is at a critical juncture in Africa (Bakare, Taiwo, Bello-Mojeed \& Munir, 2019). Contemporary scientific literature has suggested that knowledge and enlightenment about the nature and management of Autism Spectrum Disorder help to ameliorate the problems posed by the disorder (Bakare, et al., 2019). An individual with autism demonstrates persistent deficits in social communication and social interaction, including deficits in social-emotional reciprocity, non-verbal communicative behaviours used for social interaction, and deficits in developing, maintaining, and understanding relationships (American Psychological Association, 2013). Autism Spectrum Disorder (ASD) is called a spectrum or range disorder because people with the disorder can have a range of symptoms, from mild to severe, hence referred to as being in a spectrum (Willsey \& State, 2015). For example, people with ASD might have difficulties talking with others, or maintain eye contact while talking (Coury, Swedo, \& Thurm, 2014), or have restricted interests and repetitive behaviours (American Psychological Association, 2013).

The prevalence of Autism Spectrum Disorder is on the increase on a global scale. When the DSM-V was published, the American Psychiatric Association (APA) reported that the frequencies had approached 1\% of the population (American Psychological Association, 2013). In 2014, the American Center for Disease Control and Prevention (CDC) reported that one in 68 children had been identified as having a spectrum disorder, which is about 14.7 per 1,000(CDC, 2014). All groups of people are affected, regardless of culture. Samadi, Mahmoodizadeh, and McConkey (2011) reported a rate of 6.26 per 10,000 in Iran, 11.0 per 10,000 in China (Zhang \& Ji, 2005), 7.9 per 10,000 in Hong Kong (Wong \& Hui, 2008), 11.7 in Indonesia (Fombonne, 2005) and Baird, Simonoff, Pickles, Chandler, Lucas, Meldrum, \& Charman (2006) reported a rate of 116.1 per 10,000 in South Thames, United Kingdom. In sub-Saharan Africa, the population of children with an intellectual disability is on the upsurge (Boyse, 2008; Alharbi, Alharbi, Al-Thunayyan, Alsuhaibani, Alsalameh, Alhomaid, Albahouth, \& Hamid, 2019), but the exact reasons for this are yet to be determined in scientific research. However, there are global indications of the proliferation of ASD, including in Africa (Bakare, Ebigbo \& Ubochi, 2012). Despite the advancement in science, it is not clear whether autism is caused by rare gene mutations or by multi-gene interactions, and researchers have not been able to trace autism 
to a single mutation or gene abnormality (Abrahams \& Geschwind, 2008). The nature of what cause of autism is multifaceted, and this includes complex interactions between genes and the environment. While there is no consensus among researchers about the specific causes of autism, there is an unequivocal agreement that autism affects brain development (Muller, 2007).

Knowledge and awareness among secondary schools teachers play a pivotal role in early identification and management of children with ASD, but regrettably, developmental disorders in children are not considered a health priority in Africa and most teachers, are not equipped with the ability to identify developmental disabilities (Happe \& Frith, 2006). It is a logistical challenge for health personnel to screen and identify ASD among millions of pupils and students; the people best suited for this onerous task are elementary school teachers as they interact with pupils and students daily and are more likely to identify and monitor subtle signs or symptoms (Igwe, Bakare, Agomoh, Onyeama, \& Okonkwo, 2010). Lack of knowledge and awareness about childhood autism are severe obstacles in improving the health and wellbeing of children affected by autism in Nigeria (Akintunde, 2005).In an analysis of the relationship among teachers' knowledge, exposure and attitudes to Autism Spectrum Disorder, Jones (2015) found that although special educators scored significantly higher on the measure of knowledge as compared to the perception of exposure and attitude in connection to Autism Spectrum Disorder, general scores were low in terms of the participants' knowledge about the disorder, suggesting a decreased level of teacher's perception in terms of the interrelation of variables. She demonstrated that no connection was found between experience, training level, and perception of causality of ASD. Also, a study conducted by Ling, Mak, and Cheng (2010) in which they surveyed workers in Hong Kong schools to determine staff's knowledge, training, experience, and emotions related to autism showed that the level of special education training and the duration of time spent with children with autism were not significantly related to the staff's knowledge. Akogun, Njobdi and Adebukola (2018) in Educational Data, Research \& Evaluation in Nigeria (EDOREN) conducted a study on the management and implementation of the policy on special education needs and disability for improving access of person with disabilities to Nigeria basic education. Outcomes from the interview-based scoping study at the federal level showed that Nigeria's 2015 Special Needs and Disability (SNE) policy was lacking in capacity utilization, in data such as scopes and categories on SNE-learners, in at well-designed curriculum, 
and in proficiency for synchronizing among the relevant educational organizations, agencies, and parastatals within the Nigerian states. The results from the scoping study triggered a more robust qualitative field study to modify the existing policy delivery, resource allocation, administration and implementation at the secondary and tertiary levels of governance.

Agunloye, Pollingue, Davou and Osagie (2011) examined the policy and practice of special education in Nigeria. The principal focus of their study was on children with noticeable physical or neurological learning disabilities. They reported limited numbers of evaluation specialists to determine the nature of the disability, learning needs of students, and eligibility for special education services- which serve as impediments to the understanding and management of Autism Spectrum Disorder in the Nigerian education system. In a study on the management and implementation of the policy on special education needs and disability for improving access of persons with disabilities to Nigeria's basic education in Anambra State, Njobdi and Akogun (2018) found that children with special needs, especially those diagnosed with the Autism Spectrum Disorder suffer stigmatization and neglect due to the low level of awareness in their teacher's perception of ASD. The study of Alharbi, et al. (2019) on school's teachers' knowledge about autism revealed that school teachers showed a poor level of knowledge about ASD,- while the study by Ullah, Aqdas, Khan, Nabi, and Aziz (2015) at District Lower Dir, Khyber Pakhtunkhwa, Pakistan to assess the knowledge and perceptions of 240 public and private schools teachers on autism showed that $47.5 \%$ (114) know about autism through print and electronic media while $8.75 \%$ (21) know of it through training. They concluded that there is a lack of awareness regarding autism among teachers from both the sectors, but public schools' teachers were better aware of autism than private schools' teachers. The study conducted by Geraldina (2015) on Teachers' knowledge and perceived challenges of teaching children with autism in Tanzanian regular primary schools reveals that not only do teachers lack knowledge about ASD, they also lack in-service training and seminar about ASD which contributed to their poor knowledge about the disorder. In a study on the role of special educator's knowledge and training on autism, Shivarni and Joyce (2017) found that the years of experience of teachers did not show a significant relationship with the knowledge of teachers on Autism Spectrum Disorder. 


\section{Statement of Problem}

One of the most notable obstacles to the understanding and management of autism is the low level of awareness of autism in Nigerian society. When considering the level of awareness in the medical community, the perception is quite significant in healthcare practice, especially, mental health settings (Bakare, Taiwo, Bello-Mojeed \& Munir, 2019). The prevalence of autism is evident in the academic setting because autism is often classified as a learning disorder, with several in-school children in Nigeria exhibiting learning problems. The myth around autism has often led to the disorder been either not properly diagnosed or misdiagnosed coupled with the stigma attached to the disorder (Odunsi, Preece \& Garner, 2017). This stigma affects both the children and their families as they consider the public reaction to them as stereotypical and negative (Gray, 1993). Some people have even labelled children with ASD as possessed, stubborn and ill-mannered; thus, they are often maltreated or neglected in schools. Some schools cannot cope with their behaviours hence making their parents change school often for them while some are hidden at home by their parents because of shame, thus making them not to have a standard life (Bakare, et al., 2012). Socio-economic problems such as poverty, illiteracy and limited access to healthcare facilities contribute significantly to the lack of awareness perceived in the Nigerian society (Odunsi et al., 2017).

Recently, there has been an increase in the levels of awareness of autism disorder in subSaharan Africa. This has drawn the attention of global scholars and stakeholders in the problems associated with the disorder in Africa (Centers for Disease Control and Prevention CDC, 2009). However, apart from the efforts of a few individuals and non-governmental organization, only a few states in Nigeria have embarked on the campaign for autism awareness. For example, the Lagos State government has partnered with non-governmental organizations in helping to raise awareness and proffer research-proven solutions to the attendant problems associated with children with autism (Urowayino, 2018). Due to huge economic toll that autism disorder poses to the Nigerian government, the increase in healthcare expenditure associated with this disorder takes a huge toll on families and relatives of those whose ward have autism spectrum disorder. The financial constrain to both the public and the government have led to practically less awareness or sensitization to recognize neuro-psychological disorders in pupils and students at any level of the country's educational system (Bakare et al., 2012). Poor public and government 
funding has lowered the level of preparedness of our teachers to cater for the educational and social requirements of these special needs children (Nsirimobu \& Gabriel-Brisibe, 2014). The situation within the Nigerian educational system is bewildering because it is expected that special needs school should cater for all children with disabilities, but such schools have inadequate facilities to cater for the physically challenged. As a result, several schools in Nigeria are in deplorable conditions due to government's neglect and poor administration of these facilities. for instance, the teacher-student ratio is very high of students to, with many students to one teacher in the classroom. There is also limited access to healthcare professionals, portable drinking water and instructional materials and these problems adversely affect the development and learning environment of children with special needs (Nsirimobu \& Gabriel-Brisibe, 2014).

Despite global concern and public clamor for understanding and management of the increasing incidences of autism in sub-Saharan Africa, a lot of attention from government and other concerned stakeholders needs to be channeled to address this disorder in Nigeria, especially in the educational sector. However, some authors (Bakare, et al., 2019) have demonstrated that the lack of knowledge and awareness amongst teachers, researchers and even some health personnel is a function of government negligence and lack of funding for autism.

\section{Research Objectives}

The objectives of the study are as follows:

1. To examine the relationship between teachers who have a friend or family with Autism Spectrum Disorder (ASD) and their knowledge of the disorder.

2. To determine the relationship between teachers' prior training and their knowledge of ASD.

3. To access the influence of teachers' age on their knowledge about ASD.

4. To evaluate the influence of school type on teachers' knowledge of ASD.

5. To find the degree to which teachers' teaching experience will influence their knowledge about ASD.

\section{Hypotheses}

1. There is a significant relationship between teachers who have a family or a friend with Autism Spectrum Disorder and their knowledge of Autism Spectrum Disorder. 
2. There is a significant relationship between teachers who have prior training about Autism Spectrum Disorder and their knowledge about Autism Spectrum Disorder.

3. There is a significant influence of teacher's age on knowledge about Autism Spectrum Disorder.

4. School type has a significant influence on teacher's knowledge about Autism Spectrum Disorder.

5. Teachers teaching experience have a significant influence on their knowledge about ASD.

\section{Method}

\section{Research Design}

This study adopted a cross-sectional design to assess teacher's knowledge and awareness of Autism Spectrum Disorder (ASD) and data were obtained using validated psychological questionnaire for a subset of the total population of teachers in Ekiti State.

\section{Research Setting}

The study was conducted in two Local Government Areas of Ekiti State, namely, Ado Local Government and Oye Local Government, which were purposively chosen due to the number of special needs school in these local government areas.

\section{Research Participants}

Participants were made up of 107 teachers selected from 7 private and 14 public secondary schools in Ado and Oye Local Government Areas of Ekiti State, Nigeria. They consisted of 31 males $(28 \%)$ and 76 females $(71 \%)$ with an age range of 25-60years. Multi-stage sampling technique was used in this study namely; purposive sampling was used to select the 2 local government areas for the study, convenient sampling was employed to select 21 secondary schools from the two local government areas, and random sampling by balloting was used to select teachers from the schools.

\section{Research Instruments}

Data for the study was obtained using a questionnaire to collect information from the participants. The questionnaire consisted of three sections. 
Section A consisted of items measuring socio-demographic information of the participants such as gender, age, religion, teaching experience, and school type.

Section B comprised ordinary questionnaire items that measured autism awareness. This was made up of five question items with a forced-choice response style of Yes (A) or No (B), aimed at knowing if the participants were aware of Autism Spectrum Disorder. Sample questions include; Have you heard of Autism Spectrum Disorder (ASD)? Where did you first hear or read about ASD? Have you been trained to identify a child with ASD?

Section C is items on A Survey of Knowledge of Autism Spectrum Disorder (ASK-ASD) developed by Hansen (2015) and consisted of 51 items of True or False questions, each of which fell into one of five homogenous item composites namely aetiology, epidemiology, symptoms, diagnosis, and prognosis. These areas were chosen to ensure that the item pool adequately defined all aspects of ASD. After indicating each statement as True or False, participants' confidence is rated in each answer on a Likert scale, 1-Not At All Confident, 2-Confident, and 3Very Confident. True or False items are rated as 1-Correct and 0-Incorrect respectively. Items include, If a teacher believes a student has ASD/autism, he or she can give an initial diagnosis, A common initial concern of ASD/autism is a failure to develop language, Children with diets higher in sugars and processed foods show an increased risk of developing ASD/autism. Internal consistency of the scale was evaluated using Cronbach's alpha, and for actual knowledge, alpha scores ranged from .57 to .61 for the total scale and subscales. Also, average measures ICCs between the actual knowledge total scale and subscales were moderately reliable, ranging from .68 to $.77,(\mathrm{p}<.001)$. Besides, bivariate correlations between total scales at time 1 and time 2 were significant at $\mathrm{r}(64)=.63, \mathrm{p}<.001$ and $\mathrm{r}(64)=.69, \mathrm{p}<.001$ respectively (Hansen, 2015).

\section{Procedures}

The questionnaire was administered to the participants in their offices after they consented to participate in the study. An ethical issue of assurance was given to participants based on confidentiality and discretion of the study. Participants were assured of their safety and freedom to withdraw from the research at any point. The purpose of their participation was explained to them and the confidentiality of their responses was assured. Questionnaires were distributed to the participants and collation of all questionnaires was made for coding, scoring and analysis. 


\section{Statistical Analysis}

Data obtained were analyzed using the Statistical Package for the Social Sciences (SPSS) software package version 20. Demographical variables of the participants were analyzed using descriptive statistics. Hypotheses were tested using inferential statistics. Hypotheses one and two were tested using Pearson correlation while hypotheses three, four and five were tested using One-way Analysis of Variance (ANOVA). The p-value of 0.05 was used for the test of statistical significance.

\section{Results}

Table 1: Frequency table showing demographic characteristics of participants

\begin{tabular}{|c|c|c|}
\hline Demographics Variables & $\begin{array}{c}\text { Frequency } \\
\text { (n) }\end{array}$ & $\begin{array}{c}\text { Percentage } \\
(\%)\end{array}$ \\
\hline \multicolumn{3}{|l|}{ Age } \\
\hline 25-35years & 47 & 43.9 \\
\hline 36-45years & 30 & 28.0 \\
\hline Above 45 years & 24 & 22.4 \\
\hline \multicolumn{3}{|l|}{ Gender } \\
\hline Male & 31 & 28.0 \\
\hline Female & 76 & 71.0 \\
\hline \multicolumn{3}{|l|}{ Religion } \\
\hline Christianity & 102 & 95.3 \\
\hline Islam & 4 & 3.7 \\
\hline Other religion & 0 & 0 \\
\hline \multicolumn{3}{|l|}{ Teaching Experience } \\
\hline Below 5years & 38 & 35.5 \\
\hline $5-15$ years & 45 & 42.1 \\
\hline Above 15years & 21 & 19.6 \\
\hline \multicolumn{3}{|l|}{ School Type } \\
\hline Public & 72 & 67.3 \\
\hline Private & 35 & 28.0 \\
\hline
\end{tabular}


Table 2: Pearson Correlation summary showing the relationship between teachers who have a family or a friend with ASD and knowledge about ASD.

\begin{tabular}{|l|l|l|l|}
\hline \multicolumn{2}{|l|}{} & $\begin{array}{l}\text { Relationship with } \\
\text { people with Autism }\end{array}$ & $\begin{array}{l}\text { Knowledge of Autism } \\
\text { Spectrum Disorder }\end{array}$ \\
\hline $\begin{array}{l}\text { Relationship with } \\
\text { children with AUTISM }\end{array}$ & $\begin{array}{l}\text { Correlation } \\
\text { Sig. (2-tailed) } \\
\mathrm{N} \\
\text { Pearson }\end{array}$ & 105 & 105 \\
Knowledge of Autism & $\begin{array}{l}\text { Correlation } \\
\text { Spectrum Disorder }\end{array}$ & -.113 & 1 \\
\hline
\end{tabular}

Table 2 showed no significant relationship between knowledge of ASD and participants' having a relationship with family or a friend with Autism Spectrum Disorder $(\mathrm{r}(105)=-.113 \mathrm{p}>.05)$.

Table 3: Pearson correlation summary table showing the relationship between prior training and knowledge of ASD.

\begin{tabular}{|l|l|l|l|}
\hline \multicolumn{2}{|l|}{} & $\begin{array}{l}\text { Knowledge of Autism } \\
\text { Spectrum Disorder }\end{array}$ & $\begin{array}{l}\text { Prior Training on } \\
\text { Autism }\end{array}$ \\
\hline $\begin{array}{l}\text { Knowledge of Autism } \\
\text { Spectrum Disorder }\end{array}$ & $\begin{array}{l}\text { Pearson } \\
\text { Correlation } \\
\text { Sig. (2-tailed) } \\
\mathrm{N} \\
\text { Pearson } \\
\text { Correlation } \\
\text { Prior Training on Autism }\end{array}$ & 107 & \\
Sig.tailed) & .008 & 1 \\
\hline
\end{tabular}

Table 3 showed a significant relationship between knowledge of ASD and Prior training on Autism $(\mathrm{r}(107)=-.266 \mathrm{p}<.05)$. 
Table 4: One-Way ANOVA showing the influence of age on knowledge of ASD

\begin{tabular}{|l|l|c|c|c|c|} 
& Sum of Squares & df & Mean Square & F & Sig. \\
\hline Between Groups & 764.874 & 2 & 382.437 & 4.299 & .016 \\
Within Groups & 8718.373 & 98 & 88.963 & & \\
Total & 9483.248 & 100 & & & \\
\hline
\end{tabular}

As shown in Table 4, age has a significant influence on knowledge of ASD $(\mathrm{F}(2,98)=4.29 \mathrm{p}$ $<.05)$.

Table 5: One-Way ANOVA showing the influence of school type on ASD

\begin{tabular}{|l|l|l|l|l|l|}
\hline & Sum of Squares & df & Mean Square & F & Sig. \\
\hline Between Groups & 453.065 & 2 & 226.533 & 2.506 & .087 \\
Within Groups & 9402.075 & 104 & 90.405 & & \\
Total & 9855.140 & 106 & & & \\
\hline
\end{tabular}

As shown in Table 5, school type does not have a significant influence on knowledge of ASD F= $(2,104)=2.506 \mathrm{p}>.05)$.

Table 6: One-Way ANOVA showing the influence of teaching experience on knowledge on ASD

\begin{tabular}{|l|r|r|r|r|r|}
\hline & Sum of Squares & df & Mean Square & \multicolumn{1}{|c|}{ F } & Sig. \\
\hline Between Groups & 363.332 & 2 & 181.666 & 1.971 & .144 \\
Within Groups & 9491.272 & 103 & 92.148 & & \\
Total & 9854.604 & 105 & & & \\
\hline
\end{tabular}

Findings in Table 6 revealed that teaching experience does not have a significant influence on knowledge of ASD, F(2,103) = 1.971 p>.05). 
Table 7: Demographic details showing the awareness about ASD

\begin{tabular}{|l|l|l|}
\hline Respondents & Frequency & Percentage (\%) \\
\hline Aware & 103 & 96.2 \\
Not-aware & 4 & 3.8 \\
Total & 107 & 100 \\
& & \\
\hline
\end{tabular}

Table 7 above shows that $96.2 \%$ of the participants were aware of ASD while $3.8 \%$ were not aware.

Table 8: Descriptive table showing participants approach to the channel of awareness of ASD

\begin{tabular}{|l|c|c|}
\hline Approach & $\begin{array}{c}\text { Frequency } \\
(\mathbf{n})\end{array}$ & $\begin{array}{c}\text { Percentage } \\
(\boldsymbol{\%})\end{array}$ \\
\hline Television and Radio & 30 & 28 \\
\hline Newspaper & 10 & 9 \\
\hline Universities and Colleges & 58 & 54 \\
\hline Journals & 5 & 4.6 \\
\hline Other Channels & 4 & 4.4 \\
\hline
\end{tabular}

From Table 8, the result indicated that $58(54 \%)$ of the participants got the awareness of ASD in universities and colleges while 5 (4.6\%) got the awareness of ASD from the journals.

\section{Discussion}

This study investigated the knowledge and awareness of Autism Spectrum Disorder among secondary school teachers in Ekiti State. It was revealed in the study that a teacher's knowledge of Autism Spectrum Disorder has no significant relationship with him or her having a relationship with family or friend diagnosed with Autism Spectrum Disorder. This reveals that teachers, who have a relationship with an individual that has autism spectrum disorder, do not possess a significant amount of knowledge on ASD. The plausible explanation of this finding is 
that being close to someone with ASD does not equip the teacher with the necessary information on autism. Such a teacher will be more enmesh in solution-seeking than information-seeking. The current finding is consistent with the previous findings of Ling, Mak, and Cheng (2010) in which they surveyed workers in Hong Kong schools to determine the staff's knowledge, training, experience, and emotions related to autism. They found that the level of special education training and the duration of time spent with children with autism were not found to be significantly related to the staff's knowledge. This finding also corroborates the previous finding of Jones (2015) who, in her study on Teachers' perceptions of Autism Spectrum Disorder and analyzing the relationship among Teachers' knowledge, exposure, and attitudes, found low scores in terms of respondents' knowledge about the disorder, suggesting a decreased level of teacher's perception in terms of the interrelation of the variables.

This study shows a significant relationship between knowledge of ASD and prior training on Autism. This indicates that teachers who have prior training and experience with autism know about ASD. This finding suggests the importance of training of teachers, especially in the enlightenment and dissemination of information on ASD. Training is aimed at seeking for knowledge, thus showing the validity of the prior training the teachers had which has contributed to their knowledge about Autism Spectrum Disorder. However, the previous finding of Geraldina (2015) that teachers lack knowledge of ASD is an indication that there is a need to educate and train teachers to identify and manage students with Autism Spectrum Disorder. Lack of training such as in-service training, seminars, and workshops on ASD has contributed to the perceived challenges of teaching children with autism. Jones (2015) found no connection between training level and perception of causality of Autism Spectrum Disorder, but her suggestion supports this finding that school psychologists, educational administrators and other relevant stakeholders in the education industry should collaborate to create a curriculum that would integrate psychological principles in the training and management of teachers to reduce and eliminate the lack of knowledge in ASD and help aid in the development of psycho-socio based interventions.

Age was found to have a significant influence on teacher's knowledge of Autism Spectrum Disorder. This indicates that as the teachers are growing in age, maturity sets in, and they tend to acquire more knowledge and more awareness that are beneficial to them and their students, and also be aware of behaviours and attitudes exhibited by themselves and their 
students, thus revealing the contribution and importance of age of teachers to their knowledge about autism spectrum disorder. Age is synonymous to maturity, and the more teachers advance in age, the more experience they garner and the more information they acquired. This finding was in consonant with Njobdi and Akogun (2018) previous finding that a significant association exist between teacher's knowledge and level of awareness, and that as a person is growing, there is a certain knowledge that is acquired during the process; thus teachers age contributed to their knowledge about autism spectrum disorder.

Furthermore, findings show that school type has no significant influence on the teacher's knowledge about ASD. Most of the secondary schools focus more on academic curriculum which could make their students succeed, and since ASD is not part of schools' curricula, acquiring knowledge by the teachers about it may be difficult. The study conducted by Alharbi, et al. (2019) on school teachers' knowledge about autism using public and private schools revealed that school teachers showed a poor level of knowledge about Autism Spectrum Disorder. This supports the finding of the present study and shows that type of school does not bring about the knowledge of ASD.

In the same vein, the teaching experience of teachers does not have a significant influence on their knowledge of ASD. This was corroborated by the previous finding of Jones (2015) who revealed no relationship between the teaching experience of teachers and their knowledge of ASD. Also, the previous finding of Shivarni and Joyce (2017) was in consonant with the present finding when they found that years of experience of teachers did not show a significant relationship with the knowledge of teachers on Autism Spectrum Disorder.

This study also revealed that $96.2 \%$ of the participants were aware of ASD while $3.8 \%$ of them were not aware of Autism Spectrum Disorder. This indicates that most of the secondary school teachers that participated in this study were aware of ASD. This supports the previous findings that public school teachers showed more awareness of the Autism Spectrum Disorder when compared to their counterparts in private schools (Alharbi, et al., 2019; Ullah, et al., 2015). This could be a result of public enlightenment about ASD on electronic and print media, seminars and workshops, and information from friends, colleagues and family on autism. In this present study, universities and colleges were found to be the highest channels of ASD awareness (58:54\%) while the media (electronic and print) was the second-highest channel of ASD 
awareness (40:37\%). This, however, was contrary to Ullah, et al., (2015) who in their study of 240 primary school teachers in Pakistan found that $47.5 \%$ (114) of the teachers know about autism through print and electronic media while $8.75 \%$ (21) were aware of it through training. Odunsi, Preece, and Garner (2017) found a relatively low awareness of Autism Spectrum Disorder among teachers in Nigeria but was not in agreement with the present study.

\section{Conclusion}

The results of the study demonstrate that there was no significant relationship between teachers who know someone with ASD and their knowledge of ASD. Prior training on ASD has a significant relationship with teachers knowledge about ASD. Also, teachers' age has a significant influence on their knowledge about ASD. School type does not have a significant influence on teachers knowledge about ASD. Teaching experience of teachers does not have a significant influence on their knowledge about ASD. It was therefore concluded that $96.2 \%$ of the participants were aware of ASD while 3.8\% were not aware.

\section{Implication of Findings}

It is appropriate for teachers to know information about ASD as this will eliminate a lot of misconceptions and stigmatization of certain students who are considered to be dull or possessed by demons. The role of school psychologists should not be downplayed in secondary schools, as they are trained in the psychological principles and management of ASD. School psychologists can disperse knowledge about ASD quickly and efficiently by organizing training and seminars for teachers in secondary schools on the handling and management of ASD. They can organize a quarterly workshop which staff and parents could be invited to rub minds with each other while gaining important information about how to help the students.

\section{Recommendations}

The most important finding of the study is the need to educate and train secondary school teachers to identify and manage students with ASD. Therefore, more emphasis should be placed on organizing periodic seminars, workshops and conferences to equip secondary school teachers about the nature of ASD which include the aetiology, epidemiology, symptoms, diagnosis, and prognosis. This could be organized by School Management, Ministry of Education, NonGovernmental Agencies, and other stakeholders. 
Furthermore, a standard curriculum that would eliminate the lack of knowledge in ASD and help in the administration of psychological interventions should be created. Finally, psychological principles should be integrated and inculcated into secondary school teachers in the handling and management of students with ASD.

\section{References}

Abrahams, B. S., \& Geschwind, D. H. (2008). Advances in autism genetics: On the threshold of a new neurobiology. Nature Reviews Genetics, 9(5), 341-355

https://doi.org/10.1038/nrg2346

Agunloye, O. O., Pollingue, A. B., Davou, P., \& Osagie, R. (2011). Policy and practice of special education: Lessons and implications for education administration from two countries. International Journal of Humanities \& Social Science, 1(9), 90-95.

Akintunde, A. (2005). The absence of modern speech therapy in Nigeria: The Culture Perspective. Out of Africa: The spreading Self-Help Movement. Stuttering Awareness Day (ISAD) December $17^{\text {th }}$, Burkina Fasso.

Akogun, O., Njobdi \& Adebukola, A. (2018). A study of the management and implementation of the policy on special educations needs and disability for improving access of person with disabilities to Nigeria basic education. Educational Data, Research \& Evaluation in Nigeria (EDOREN) Thematic Research Study, 6.

Alharbi, K. A., Alharbi, A. A., Al-Thunayyan, Alsuhaibani K. A., Alsalameh, N. S., Alhomaid, M. H., Albahouth, I . S. \& Hamid, P. F. (2019). School's teacher's knowledge about autism in Al-Badayacity, Al-Qassim region, Kingdom of Saudi Arabia. Mater Sociomed, 31(1), 4-9. https://doi.org/10.5455/msm.2019.31.4-9

American Psychiatric Association. (2013). Diagnostic and statistical manual of mental disorders (5th ed.). https://doi.org/10.1176/appi.books.9780890425596

Baird, G., Simonoff, E., Pickles, A., Chandler, S., Lucas, T., Meldrum, D., \& Charman, T. (2006). Prevalence of Disorders of the Autism Spectrum in a Population Cohort of Children in South Thames: The Special Needs and Autism Project (SNAP). Lancet 368(9531), 210215 doi:10.1016/S0140-6736(06)69041-7 
Bakare, M. O., Ebigbo, P. O. \& Ubochi, V. (2012). Prevalence of Autism Spectrum Disorder among Nigerian children with intellectual disability: A stopgap assessment. Journal of Healthcare for the Poor \& Underserved, 23(2), 513-518.

https://doi.org/10.1353/hpu.2012.0056

Bakare, M. O., Taiwo, O. G., Bello-Mojeed, M. A., \& Munir, K. M. (2019). Autism spectrum disorders in Nigeria: A scoping review of literature and opinion on future research and social policy directions. Journal of Health Care for the Poor \& Underserved, 30, (3), 899909. https://doi.org/10.1353/hpu.2019.0063

Boyse, K. (2008). Autism, autistic spectrum disorders (ASD) and pervasive developmental disorders (PDD). Your Child Development and Behavior Resources: A guide to information and support for parents (pp. 1). University of Michigan

Centers for Disease Control and Prevention (CDC) (2009). Prevalence of Autism Spectrum Disorders. Autism and Developmental Disabilities Monitoring Network, United States, 2006. MMWR Surveillance Summaries.

Centers for Disease Control and Prevention (CDC) (2014). CDC Informational Briefing on Autism: Findings from the Latest Prevalence Report Autism and Developmental Disabilities Monitoring (ADDM) Network 11 Sites, United States, 2010. Meeting of the Interagency Autism Coordinating Committee, National Institutes of Health Bethesda, Maryland April 8, 2014

Coury, D. L., Swedo, S. E., \&Thurm, A. E. (2014). Treating the whole person with Autism. The proceedings of the Autism Speaks. National Autism Conference. https://doi.org/10.1016/j.cppeds.2013.12.002

Edward, G. (2015). Teachers' knowledge and perceived challenges of teaching children with autism in Tanzania regular primary schools. International Journal of Academic Research and Reflection, 3(5), 36-47.

Fombonne, E. (2005). The changing epidemiology of autism. Journal of Applied Research in Intellectual Disabilities, 18(4), 281-294. https://doi.org/10.1111/j.1468-3148.2005.00266.x 
Gray, E. D. (1993). Perceptions of stigma: the parents of autistic children. Sociology of Health and Illness, 15(1), 102-120. https://doi.org/10.1111/1467-9566.ep11343802

Hansen, L. K. (2015). Development and Validation of a Survey of Knowledge of Autism Spectrum Disorder. Master's Theses. 141. https://aquila.usm.edu/masters_theses/141

Happe F. \& Frith, U. (2006). The weak coherence account: detail-focused style in autism spectrum disorders. Journal of Autism Development \& Disorder; 36(1),5-25. https://doi.org/10.1007/s10803-005-0039-0

Igwe, M. N., Bakare, M. O, Agomoh, A. O., Onyeama, G. M, \& Okonkwo, K. O. (2010). Factors influencing knowledge about childhood autism among final year undergraduate medical, nursing and psychology students of University of Nigeria, Enugu State. Unpublished Thesis. https://doi.org/10.1186/1824-7288-36-44

Jones, N. (2015). Teacher's perception of Autism Spectrum Disorder: An analysis of the relationship among teacher's knowledge, exposure and attitudes. PCOM Psychology Dissertations. 350.https://digitalcommons.pcom.edu/psychology_dissertations/350

Ling, C., Mak, W., \& Cheng, J. (2010). Attribution model of stigma towards children with autism in Hong Kong. Journal of Applied Research in Intellectual Disabilities, 23, 237-249. https://doi.org/10.1111/j.1468-3148.2008.00456.x

Müller R. A. (2007). The study of autism as a distributed disorder. Mental Retard Development Disability Resources Review, 13(1), 85-95. https://doi.org/10.1002/mrdd.20141

Njobdi, S. \& Akogun, O. (2018).A study of the management and implementation of the policy on special education needs and disability for improving access of persons with disabilities to Nigeria's Basic education in Anambra State. Education Data, Research and Evaluation in Nigeria, Abuja, Nigeria. Supported by UK Aid

Nsirimobu, P. \& Gabriel-Brisibe, C. U. (2014). Awareness of autism amongst school teachers in Yenagoa city, Bayelsa State. Nigerian Journal of Paediatrics, 42(1), 46-49. https://doi.org/10.4314/njp.v42i1.10

Odunsi, R., Preece, D. \& Garner, P. (2017). Nigerian teachers' understanding of Autism Spectrum Disorder: A comparative study of teachers from urban and rural areas of Lagos 
State. Disability, CBR \& Inclusive Development, 28(3), 4-11.

https://doi.org/10.5463/dcid.v28i3.637

Samadi, S. A., \&McConkey, R. (2011). Autism in Developing Countries: Lessons from Iran. Autism Research and Treatment, (pp 1-11). Hindawi Publishing Corporation. doi: $10.1155 / 2011 / 145359$

Shivarni, T., \& Joyce, J. (2017). Special educator's knowledge and training on autism in Karnataka: A cross-sectional study. Indian Journal of Psychiatry, 59(3), 359-365. https://doi.org/10.4103/psychiatry.IndianJPsychiatry_133_17

Ullah, S., Aqdas, M. I., Khan, N., Nabi, G., \& Aziz, T. (2015). Awareness Regarding Autism in Schools' Teachers at District Lower Dir, Khyber Pakhtunkhwa, Pakistan. Universal Journal of Medical Science 3(3), 55-59. doi: 10.13189/ujmsj.2015.030301.

Urowayino, J. (2018). Greensprings partners NGO to create Autism awareness. Vanguard Newspapers, 12 December 2018.

https://www.google.com/amps/s/www.vanguardngr.com/2018/12/greensprngs-partners-ngoto-create-autism-awareness/amp/.

Willsey, A. J., \& State, M. W. (2015). Autism spectrum disorders: From genes to neurobiology. Current Opinion Neurobiology, 30,92-99. https://doi.org/10.1016/j.conb.2014.10.015

Wong, V. C. N., \& Hui, S. L. H. (2008). Epidemiological study of autism spectrum disorder in China. Journal of Child Neurology, 23(1), 67-72.

https://doi.org/10.1177/0883073807308702

Zhang, X., \& Ji, C. Y. (2005). Autism and mental retardation of young children in China. Biomedical and Environmental Sciences, 18(5), 334-340. 